\title{
Consumption of antibiotics in a small Pacific island nation: Samoa
}

\author{
Pauline NORRIS, Hong Anh NGUYEN.
}

\begin{abstract}
${ }^{*}$
High levels of antibiotic use contribute to development of antibiotic resistance. There is little known about levels of antibiotic use in Samoa, although anecdotally, there are high levels of use, and a strain of methicillin-resistant Staphylococcus aureus may have developed there.

The study aimed to gather basic data on levels of antibiotic use in Samoa.

All those who import medicines into Samoa were interviewed; invoices, prescription records in hospitals, pharmacies and health centres were reviewed; and prospective observation was carried out in private pharmacies.

Analysis of orders made in one year provided an estimate of overall antibiotic consumption of 37.3 Defined Daily Doses (DDDs) per 1000 inhabitant days. Penicillins comprised $63 \%$ of DDDs used. Antibiotics were around a third of all prescribed drugs in hospitals and pharmacies, and $44 \%$ of those dispensed in health centres. Approximately two-thirds of prescriptions dispensed included an antibiotic. A quarter of antibiotic sales in pharmacies were without a prescription.

Samoa has high rates of use of antibiotics and very high reliance on penicillins, compared to other developing countries. Levels of prescribing are high compared with other developing nations. It is feasible to calculate total consumption of medicines in very small developing nations.
\end{abstract}

Keywords: Drug Utilization. Anti-Bacterial Agents. Samoa.

\begin{abstract}
RESUMEN
El uso de altas cantidades de antibióticos contribuye al desarrollo de resistencias a antibióticos. Se sabe poco sobre el consumo de antibiótico en Samoa, aunque paradójicamente, hay elevados niveles de consumo y puede haberse instalado una cepa de Estafilococo aureus metilcilin-resistente.

El estudio intentó reunir datos básicos sobre los niveles de consumo de antibióticos en Samoa. Se entrevistó a todos los que importan antibióticos en Samoa; se revisaron las facturas, los registros de prescripciones de hospitales, de farmacias y de centros de salud; y se realizó una observación prospectiva en las farmacias privadas.

El análisis de las recetas de un año proporcionó una estimación de consumo total anual de 37,3 Dosis Diarias Definidas (DDD) por 1000 habitantes y día. Las penicilinas suponían el 63\% de las DDD utilizadas. Los antibióticos suponían un tercio de todos los medicamentos prescritos en hospitales y farmacias, y el $44 \%$ de los dispensados en centros de salud. Aproximadamente dos tercios de las recetas dispensadas incluían un antibiótico. La cuarta parte de las dispensaciones de antibióticos eran sin receta.

Samoa tiene una alta tasa de uso de antibióticos y mucha confianza en las penicilinas, comparada cono tros países en vías de desarrollo. Los niveles de prescripción son altos comparados con otros países en desarrollo. Es factible calcular el consumo total de medicamento sen países muy pequeños en vías de desarrollo.
\end{abstract}

Palabras clave: Utilización de medicamentos. Agentes antibacterianos. Samoa.

\section{(English)}

\section{INTRODUCTION}

There is considerable concern internationally about rising levels of antimicrobial resistance. ${ }^{1,2}$ Antibiotic resistance has now become a serious problem in many countries, in part because no new classes of antibiotics have been developed for decades. ${ }^{3}$ Resistance develops wherever antibiotics are used, whether this use is appropriate or inappropriate, but inappropriate use increases resistance without giving benefits to patients. ${ }^{4}$ There is considerable data available showing inappropriate use in developed countries. ${ }^{5-8}$
*Pauline NORRIS. PhD. Senior Lecturer. School of Pharmacy, University of Otago. Dunedin (New Zealand). Hong Anh NGUYEN. BPharm. Wanganui Hospital, Whanganui District Health Board. Whanganui (New Zealand). 
While studies show high levels of antibiotic use and resistance in some developing countries, ${ }^{9-13}$ many developing countries lack data on either use or resistance. Carrying out research on drug utilisation in developing countries can sometimes be challenging. In Samoa, there is no published data available on antibiotic consumption or resistance, although it is thought that a strain of communityacquired MRSA originated from Samoa. ${ }^{14}$ Excessive use of antibiotics, including use for inappropriate conditions, is acknowledged as a problem by health professionals in Samoa. Antibiotics are not legally available without prescription from pharmacies, although in practice they are available. While total consumption of antibiotics is likely to be the critical factor in selecting resistance, under-use through inadequate dosing, and poor adherence by patients may also be important. ${ }^{2}$ There are anecdotal reports, and interview data (as yet unpublished) suggests that these are also considerable problems in Samoa.

Samoa (formerly known as Western Samoa) consists of two large and some small islands in the South Pacific. The population is about 177,000 , and the only city, Apia, is home to about 35,000 people. The health system is largely publicly funded $(75.9 \%)$, with some contribution from development aid $(8.7 \%)$. $^{15}$ Many Samoans migrate to New Zealand, Australia and the USA, and there is substantial movement between these countries. In the latest New Zealand Census (2001) 115,000 Samoan people lived in New Zealand, of whom $58 \%$ were born in New Zealand. ${ }^{16}$ In Australia more than 50,000 people report Samoan ancestry ${ }^{17}$, and 133,000 people in the US reported Samoan as one of their ethnicities. ${ }^{18}$ Thus, if levels of antibiotic resistance are high in Samoa, this may have significant implications for the spread of resistance in these other countries.

In Samoa medicines for the public health care system are imported by the Ministry of Health, and then distributed to hospitals and health centres. Private pharmacies import medicines from wholesalers and the private hospital imports some medicines for use by in- and out-patients.

General practitioners do not usually dispense medicines although they may keep small stocks for emergencies, and one GP outside of Apia dispenses. Antibiotics are dispensed to consumers by: the four privately-owned community pharmacies in Apia (there are no private pharmacies outside of Apia); hospital pharmacies (both in-patients and out-patients at one public and one private hospital in Apia, and one public in Tuasivi on the other large island); and by nurses (and occasionally doctors) in other health centres outside Apia and Tuasivi (9 in total). Samoa has a severe shortage of trained personnel, with only about 40 doctors (almost all in Apia or Tuasivi) and seven qualified pharmacists (all based in Apia).

The aim of this study was to gather basic data on levels of antibiotic use in Samoa.

\section{METHODS}

Methods used were interviews with healthcare providers and examination of invoices; retrospective record review in hospitals, pharmacies and health centres, and prospective observation in private pharmacies. Ethical approval for the study was given by the Samoa Health Research and Ethics committee.

Total consumption of antibiotics in Samoa was obtained through reviewing invoices, records of orders, and by interviews with healthcare providers (collectively referred to as "ordering data" below). In the public hospital in Apia (which purchases on behalf of all the public health services, and also the dispensing GP) all orders for 2004 were recorded. Invoices for four months were obtained from one private pharmacy (as the basis for estimating yearly use). For the other two private pharmacies who purchase medicines (the fourth is supplied by one of these) and the private hospital, the person responsible for ordering was asked to estimate use of each formulation of each antibiotic for 2004.

Retrospective record review was used to determine: the proportion of prescriptions which included antibiotics, the quantity of antibiotics dispensed per prescription, the number of prescriptions in a one month period, and the overall amount dispensed in a month. Records examined were paper records of prescriptions in pharmacies, and entries into logbooks in health centres (medicines are prescribed and dispensed by the same staff in these centres and paper prescriptions are not used). Data was collected from all outlets for antibiotics in Samoa apart from one private pharmacy, and some rural health centres which have visits from nurse or doctor once a week, and are otherwise staffed by an enrolled nurse who does not prescribe antibiotics.

We aimed to examine all records for the month of November 2004, in order to avoid the Christmas period, when Samoa has a large influx of visitors. There is very little seasonal variation in temperature or weather, so there is no reason to assume that November would be different from other months. However some pharmacies and health centres were not able to show us their records for that period, because these had been discarded or mislaid. In these cases we took whatever period was available after November. In the main hospital we took a simple random sample of prescriptions (every ninth prescription) in November, because the number of prescriptions was unmanageably large. HAN spent several hours helping with dispensing at several of the pharmacies before data collection began, in order to find out how the dispensing was carried out, since it did not always match the prescription (e.g. in the hospital a standard $100 \mathrm{ml}$ bottle was dispensed when any quantity of suspension was prescribed).

In the hospitals and private pharmacies paper prescriptions were examined and details of how these would have been dispensed recorded on standard forms. Where necessary we asked pharmacy staff for advice. In the hospitals and 
private pharmacies we can identify the proportion of prescription clients who received an antibiotic. In the health centres, dispensing is recorded in books, divided into sections for each type of medicine. We recorded all medicines dispensed in our study period, but the organization of these books meant that although we could identify the proportion of medicines which were antibiotics, we could not identify discrete individual patients, and therefore were unable to determine the proportion of clients who received antibiotics.
One health centre recorded all patients seen, symptoms, diagnosis and treatment. We collected data on a series of 120 consecutive patients to see what kind of symptoms are presented to rural health centres, and the diagnoses for which antibiotics were dispensed.

Prospective data collection was used to identify the number of patient encounters where antibiotics are dispensed, and the proportion of antibiotic sales which were non-prescription. This took place over one day in each of two private pharmacies.

\begin{tabular}{|c|c|c|c|c|c|c|}
\hline ATC code & Drug & Formulation & total $\mathrm{g}$ & DDDs & $\%$ public & $\begin{array}{l}\text { DDD/1000 } \\
\text { inh-days }\end{array}$ \\
\hline \multirow{3}{*}{ J01CA04 } & Amoxicillin & tablets/capsules & 784,593 & 784,593 & $95.6 \%$ & \\
\hline & & Suspensions & 90,800 & 90,800 & $82.6 \%$ & \\
\hline & & TOTAL & 875,393 & 875,393 & & 13.55 \\
\hline J01CA01 & Ampicillin & tablets/capsules & 2,000 & 1,000 & $0.0 \%$ & 0.02 \\
\hline \multirow[t]{3}{*}{ J01CR02 } & $\begin{array}{l}\text { Augmentin } \\
\text { (co-amoxyclav) }\end{array}$ & tablets/capsules & 198,057 & 198,057 & $94.7 \%$ & \\
\hline & & Suspensions & 24,775 & 24,775 & $88.3 \%$ & \\
\hline & & TOTAL & 222,832 & 222,832 & & 3.45 \\
\hline J01FA10 & Azithromycin & tablets/capsules & 452 & 1,505 & $0.0 \%$ & 0.02 \\
\hline J01DC04 & Cefaclor & tablets/capsules & 3,950 & 3,950 & $0.0 \%$ & \\
\hline \multirow[t]{2}{*}{ J01DC04 } & Cefaclor & Suspensions & 8,340 & 8,340 & $89.9 \%$ & \\
\hline & & TOTAL & 12,290 & 12,290 & & 0.19 \\
\hline J01DB01 & Cephalexin (Keflex) & tablets/capsules & 26,250 & 13,125 & $95.2 \%$ & 0.20 \\
\hline \multirow[t]{3}{*}{ J01BA01 } & Chloramphenicol & tablets/capsules & 32,000 & 10,667 & $93.8 \%$ & \\
\hline & & Suspensions & 3,965 & 1,322 & $94.6 \%$ & \\
\hline & & TOTAL & 35,965 & 11,988 & & 0.19 \\
\hline J01MA02 & Ciprofloxacin & tablets/capsules & 190,475 & 190,475 & $98.4 \%$ & 2.95 \\
\hline J01FF01 & Clindamycin & tablets/capsules & 5 & 4 & $0.0 \%$ & 0.00 \\
\hline \multirow[t]{6}{*}{ JO1CF02 } & Cloxacillin & tablets/capsules & 262,000 & 131,000 & $95.4 \%$ & \\
\hline & & Suspensions & 64,000 & 32,000 & $97.7 \%$ & \\
\hline & & TOTAL & 326,000 & 163,000 & & 2.52 \\
\hline & Co-trimoxazole & tablets/capsules & 406,217 & & $94.5 \%$ & \\
\hline & & Suspensions & 27,514 & & $87.2 \%$ & \\
\hline & & TOTAL & 433,731 & 180,721 & & 2.80 \\
\hline J01AA02 & Doxycycline & tablets/capsules & 4,660 & 46,600 & $0.0 \%$ & 0.72 \\
\hline \multirow[t]{3}{*}{ J01FA01 } & Erythromycin & tablets/capsules & 210,125 & 210,125 & $95.2 \%$ & \\
\hline & & Suspensions & 27,550 & 27,550 & $90.7 \%$ & \\
\hline & & TOTAL & 237,675 & 237,675 & & 3.68 \\
\hline \multirow[t]{3}{*}{ J01CF05 } & Flucloxacillin & tablets/capsules & 267,750 & 133,875 & $93.4 \%$ & \\
\hline & & Suspensions & 36,700 & 18,350 & $95.4 \%$ & \\
\hline & & TOTAL & 304,450 & 152,225 & & 2.36 \\
\hline J01XD01 & Metronidazole & tablets/capsules & 169,400 & 112,933 & $94.5 \%$ & 1.75 \\
\hline J01MA06 & Norfloxacillin & tablets/capsules & 260 & 325 & $0.0 \%$ & 0.01 \\
\hline J01CE02 & Penicillin V & tablets/capsules & 177,750 & 88,875 & $98.5 \%$ & \\
\hline \multirow[t]{2}{*}{ J01CE02 } & Penicillin V & Suspensions & 37,685 & 18,843 & $99.5 \%$ & \\
\hline & & TOTAL & 215,435 & 107,718 & & 1.67 \\
\hline \multirow[t]{2}{*}{ J01AA07 } & Tetracycline & tablets/capsules & 77,750 & 77,750 & $80.4 \%$ & 1.20 \\
\hline & TOTAL ANTIBIOTICS & & & $4,190,680$ & & 37.27 \\
\hline
\end{tabular}

\section{RESULTS}

Ordering data were obtained from all importers of antibiotics. Table 1 shows total consumption for Samoa in 2004 in grams, Defined Daily Doses (DDDs), and DDDs per 1000 inhabitants per day. The percentage of each drug and formulation which was ordered for the public sector is also presented.

Almost two-thirds of antibiotics consumed were penicillins (63\% of DDDs/1000inh-days). Macrolides made up $9.9 \%$ of consumption, quinolones $7.9 \%$, sulphanamides and trimethoprim $7.5 \%$, tetracyclines $5.2 \%$. Consumption of cephalosporins was low (1\%), and other antibiotics made up $5.2 \%$ of consumption.
Other antibiotic formulations ordered in 2004 were 3748 bottles of eye-drops, 4025 bottles of eardrops and 38,400 tubes of creams. This is the equivalent of one bottle of eye-drops per 47 people, one bottle of ear-drops per 44 people, and one tube of antibiotic cream per 4.6 people.

Table 2 shows data from retrospective record review in the two hospitals, three private pharmacies, and five health centres studied. The percentage of prescriptions containing an antibiotic was similar in hospitals and private pharmacies. Antibiotics were a larger proportion of all items dispensed in health centres, but there was 
considerable variation between the health centres (range: $28.4-73.3$ ).

Eighty percent of prescriptions examined were for oral dosage forms (tablet, capsules or suspensions). The most commonly dispensed antibiotics were amoxycillin (29.6\%) flucloxacillin $(15.4 \%)$, co-trimoxazole $(12.0 \%)$, cloxacillin $(9.7 \%)$, erythromycin (8.3\%), augmentin (7.1\%), and penicillin $\mathrm{V}(6.4 \%)$. The average length of supply was 6.88 days.

\begin{tabular}{|c|c|c|c|c|}
\hline Healthcare facility & $\begin{array}{c}\text { Number of } \\
\text { prescriptions in one } \\
\text { month (a) }\end{array}$ & $\begin{array}{l}\text { Percentage of } \\
\text { prescriptions } \\
\text { containing an } \\
\text { antibiotic }\end{array}$ & $\begin{array}{l}\text { Number of } \\
\text { medicines } \\
\text { dispensed }\end{array}$ & $\begin{array}{c}\text { Antibiotics as a } \\
\text { proportion of } \\
\text { medicines } \\
\text { dispensed }\end{array}$ \\
\hline Main public hospital & 5,247 & 68.3 & 11,709 & 29.2 \\
\hline Second public hospital & 1,663 & 58.0 & 3,823 & 34.7 \\
\hline HOSPITALS & 6,910 & 65.8 & 15,613 & 34.6 \\
\hline Private pharmacy 1 & 808 & 68.8 & 1,637 & 39.8 \\
\hline Private pharmacy 2 & 82 & 80.5 & 457 & 50.7 \\
\hline Private pharmacy 3 & 654 & 68.2 & 1,440 & 38.8 \\
\hline PHARMACIES & 1,544 & 69.2 & 3,534 & 36.4 \\
\hline Health centre1 & Data unavailable & & 308 & 45.8 \\
\hline Health centre 2 & Data unavailable & & 191 & 73.3 \\
\hline Health centre 3 & Data unavailable & & 457 & 52.5 \\
\hline Health centre 4 & Data unavailable & & 296 & 28.4 \\
\hline Health centre 5 & Data unavailable & & 601 & 35.1 \\
\hline HEALTH CENTRES & Data unavailable & & 1,853 & 44.0 \\
\hline TOTAL & & 66.4 & & 34.68 \\
\hline
\end{tabular}

Prospective observation showed that non prescription sale of antibiotics accounted for $24.7 \%$ (20/81) of total antibiotic sales on the days studied. The two pharmacies observed sold a similar proportion of antibiotics without prescription (23.8\% in one pharmacy, and $25.6 \%$ in the other). The average intended length of supply for the over the counter antibiotics was 5.0 days. Flucloxacillin $500 \mathrm{mg}$ and tetracycline $250 \mathrm{mg}$ were the most common antibiotics purchased over the counter.

Of the 122 patients recorded in the health centre book, $30(24.6 \%)$ were recorded as receiving an antibiotic. Diagnoses were recorded for 29 of these. Seven patients were given antibiotics for wounds, six for upper respiratory tract infections, five for abscesses, two for pneumonia, two for gastritis, one for rheumatic fever, one for otitis media, one for bronchiolitis, one for cellulitis, one for conjunctivitis, one chronic obstructive respiratory disease, and one dermatitis.

\section{DISCUSSION}

Data on overall consumption of medicines in DDDs are seldom available from developing countries, because this usually requires a high level of computerization. In developed countries such data are usually obtained from wholesalers or reimbursement systems. Because Samoa is so small it is possible to gather data on overall consumption by requesting it from all those who import medicines, and using paper records. This study found an overall use of antibiotics of 37.3 DDDs per 1000 inhabitant-days in Samoa. This is higher than that reported in any European country. Goossens et al report that in 26 European countries outpatient antibiotic consumption varied from 10.0 DDD per 1000 inhabitant-days in the Netherlands to 32.2 in France. ${ }^{19}$ They report that outpatient data represents 90 to $94 \%$ of all use, and in fact their data includes hospital use in some countries.

Data on antibiotic consumption in developing countries is usually expressed using the WHO/INRUD indicator, percentage of encounters with an antibiotic prescribed. ${ }^{20}$ In practice researchers often look at the percentage of prescriptions which include an antibiotic. Between 1988 and 2002, published and unpublished studies found that on average 40 to $60 \%$ of patients in health facilities in developing countries were prescribed antibiotics. ${ }^{21}$ Antibiotic use in Samoa also appears to be high by this standard. In public hospitals and private pharmacies, $66.4 \%$ of prescriptions included an antibiotic. It seems likely that this figure is even higher in health centres, because antibiotics form a higher proportion of medicines dispensed there. Considerable variation was found between the five health centres studied, and this suggests that prescribers may vary substantially in their prescribing habits.

Both the aggregate consumption data and the prescription analysis suggest a high level of use of penicillins compared to that found in other developing countries. For example in Kenya, penicillins made up only $31 \%$ of antibiotic consumption, ${ }^{22}$ and in a Sri Lankan study $37.7 \%$ of all prescriptions, and $42.9 \%$ of prescriptions for children were for penicillin. ${ }^{23,24}$ In a Malaysian study erythromycin was the most commonly prescribed antibiotic in primary care, ${ }^{25}$ while in Samoa it accounted for only $10 \%$ of use expressed in DDDs.

By law, antibiotics are not available over the counter in pharmacies in Samoa. However, in practice, many antibiotics are purchased in this way. This is common in many developing countries. In Samoa, pharmacy staff report selling antibiotics over the counter for a range of reasons, such as patient 
inability to afford to see a doctor, long waiting times at the hospital, and concern that untreated infections may become serious. Much of the over the counter sale is reported to be for self-treatment for boils. There is little evidence of very short courses of antibiotics being dispensed, as has been reported in other developing countries. ${ }^{26,27}$ The prevalence of over the counter sales of antibiotics means that studies based on prescriptions are likely to significantly under-estimate the volume of antibiotics sold in pharmacies.

Drug utilization research in developing countries presents some difficulties, and therefore the study methodology varied from the ideal. The destruction or loss of paper records meant that the sampling timeframe varied somewhat in different facilities. Ideally the period of prospective observation in pharmacies would have been longer. Our method of obtaining ordering data relied in two cases on pharmacist or doctor recall of orders (with prompting). However together these form a small proportion of the total consumption. The most significant orderer was the public hospital in Apia and paper records were used there. The final result may still be a slight-underestimate because some supplementary orders by the hospital may not have been recorded. On the other hand volumes in private pharmacies may be slight over-estimates because sometimes people purchase quite large quantities of antibiotics in Samoa to take to New Zealand, where they are not available without a prescription, and are more expensive. The study has shown that in very small developing countries it is possible to calculate total consumption of medicines in DDDs.

The high level of use of antibiotics in Samoa is concerning. Further research is need on resistance levels, and appropriate strategies to reduce antibiotic use should be implemented.

\section{ACKNOWLEDGEMENTS}

We want to thank all the extremely helpful healthcare providers in Samoa, the Health Research Council of New Zealand for funding HAN's summer studentship, and the University of Otago for PN's research and study leave.

\section{References}

1. Standing Medical Advisory Committee Sub-Group on Antimicrobial Resistance, The Path of Least Resistance. 1998, Department of Health (UK). URL: http://www.advisorybodies.doh.gov.uk/smac1.htm (accessed 18-02-2007)

2. World Health Organisation. WHO Global Strategy for Containment of Antimicrobial Resistance. Geneve: WHO; 2001.

3. Amyes SG. The rise in bacterial resistance is partly because there have been no new classes of antibiotics since the 1960s. BMJ. 2000 Jan 22;320(7229):199-200.

4. Ellis-Pegler RB. Antimicrobial resistance--can we, should we do anything about it? N Z Med J. 1999;112(1096):349-51.

5. McGregor A, Dovey S, Tilyard M. Antibiotic use in upper respiratory tract infections in New Zealand. Fam Pract. 1995 Jun;12(2):166-70.

6. Kljakovic M. Durham J. Sore throat diagnosis and management in a general practice after-hours service. N Z Fam Physician 1999;26(6):47-50.

7. van Duijn HJ, Kuyvenhoven MM, Schellevis FG, Verheij TJ. Determinants of prescribing of second-choice antibiotics for upper and lower respiratory tract episodes in Dutch general practice. J Antimicrob Chemother. 2005;56(2):420-2.

8. Mazzaglia G, Caputi AP, Rossi A, Bettoncelli G, Stefanini G, Ventriglia G, Nardi R, Brignoli O, Cricelli C. Exploring patient- and doctor-related variables associated with antibiotic prescribing for respiratory infections in primary care. Eur J Clin Pharmacol. 2003;59(8-9):651-7.

9. Schorling JB, De Souza MA, Guerrant RL. Patterns of antibiotic use among children in an urban Brazilian slum. Int J Epidemiol. 1991;20(1):293-9.

10. Larsson M, Kronvall G, Chuc NT, Karlsson I, Lager F, Hanh HD, Tomson G, Falkenberg T. Antibiotic medication and bacterial resistance to antibiotics: a survey of children in a Vietnamese community. Trop Med Int Health. 2000;5(10):711-21.

11. Thamlikitkul V. Antibiotic dispensing by drug store personnel in Bangkok, Thailand. J Antimicrob Chemother. 1988 Jan;21(1):125-31.

12. Montefiore D, Rotimi VO, Adeyemi-Doro FA. The problem of bacterial resistance to antibiotics among strains isolated from hospital patients in Lagos and Ibadan, Nigeria. J Antimicrob Chemother. 1989;23(4):641-51

13. Okumura J, Wakai S, Umenai T. Drug utilisation and self-medication in rural communities in Vietnam.. Soc Sci Med. 2002;54(12):1875-86.

14. Smith JM, Cook GM, A decade of community MRSA in New Zealand. Epidemiol Infect. 2005 Oct;133(5):899-904

15. World Health Organisation. Core Health Indicators from the World Health Report: WHOSIS. Geneve: WHO; 2005.

16. Statistics New Zealand, Pacific Profiles - Samoan.

17. Australian Bureau of Statistics, Australian Social Trends: Population - Population characteristics: Ancestry of Australia's Population. 2003, Australian Bureau of Statistics.

18. US Census, Tongan Population: Native Hawaiians and other Pacific Islanders. 2000.

19. Goossens H, Ferech M, Vander Stichele R, Elseviers M; ESAC Project Group. Outpatient antibiotic use in Europe and association with resistance: a cross-national database study. Lancet. 2005;365(9459):579-87.

20. World Health Organisation, Department of Essential Drugs and Medicines Policy. How to investigate drug use in health facilities: selected drug use indicators. Geneve: World Health Organisation; 1993. p. 87.

21. Holloway K, Ivanovska V. Measuring use of medicines: progress in the last decade. in ICIUM (International Conference on Improving the Use of Medicines). 2004. Chaing Mai, Thailand. 
22. Mitema ES, Kikuvi GM. Surveillance of the overall use of antimicrobial drugs in humans over a 5 year period (19972001) in Kenya. J Antimicrob Chemother. 2004 Nov;54(5):966-7.

23. Angunawela II, Diwan VK, Tomson G. Experimental evaluation of the effects of drug information on antibiotic prescribing: a study in outpatient care in an area of Sri lanka. Int J Epidemiol. 1991 Jun;20(2):558-64.

24. Tomson G, Diwan V, Angunawela I. Paediatric prescribing in out-patient care. An example from Sri Lanka. Eur J Clin Pharmacol. 1990;39(5):469-73.

25. Teng CL, Achike FI, Phua KL, Norhayati Y, Nurjahan MI, Nor AH, Koh CN. General and URTI-specific antibiotic prescription rates in a Malaysian primary care setting. Int J Antimicrob Agents. 2004;24(5):496-501.

26. Chalker J, Ratanawijitrasin S, Chuc NT, Petzold M, Tomson G. Effectiveness of a multi-component intervention on dispensing practices at private pharmacies in Vietnam and Thailand--a randomized controlled trial.. Soc Sci Med. 2005;60(1):131-41.

27. Wolffers I. Drug information and sale practices in some pharmacies of Colombo, Sri Lanka. Soc Sci Med. 1987;25(3):319-21 